\title{
Radioembolization Treatment for Liver Cancer
}

\author{
Ezgi Başak ERDOĞAN ${ }^{1}$, Hüseyin ÖZDEMIR², Mehmet AYDIN ${ }^{1}$ \\ ${ }^{1}$ Department of Nuclear Medicine, Bezmialem Vakif University School of Medicine, İstanbul, Turkey \\ ${ }^{2}$ Department of Radiology, Bezmialem Vakif University School of Medicine, İstanbul, Turkey
}

\section{ABSTRACT}

Although curative treatment is surgery (resection/transplantation) and for small lesions ablative strategies, in primary liver carcinomas such as hepatocellular carcinoma and cholangiocellular carcinoma, palliative treatment is used for most of these patients because of lack of surgical options. These treatments are regional treatments such as transarterial chemoembolization, radiofrequency ablation, or microwave ablation and systemic treatments such as tyrosine kinase inhibitors. Surgery and chemotherapy are the main treatment options for metastatic liver tumors, particularly in colorectal tumors, although local treatment options are used for these patients. In recent years, transarterial radioembolization with yttrium- 90 microsphere has emerged as a local treatment option in primary and metastatic liver tumors. The aim of this treatment is to provide an effective radiation dose distribution for the tumor in the liver tissue and to give the lowest dose in order to not harm the intact liver tissue. Radioembolization has proven to be as effective as other available palliative treatments in primary and secondary liver tumors and is a treatment method that is well tolerated. It has a risk for serious life-threatening complications, although this rate is low. Toxicity can be kept at a minimum with adequate technical and rigorous application in experienced hands and in accordance with multidisciplinarity. It is hoped that the effectiveness of radioembolization is further increased in the future by technological developments, researches on dosimetry, its use along with radiosensitizing agents, and various treatment combinations.

Keywords: Radioembolization, Yttrium-90 microsphere, liver treatment

\section{Introduction}

Hepatocellular carcinoma (HCC) is one of the world's most common abdominal malignancies. Most patients have an underlying liver disease. The stage of tumor and the functional capacity of the liver determine the prognosis. A practical staging system based on the tumor burden, the liver function reserve, physical condition, and symptoms associated with cancer was developed by the Barcelona group (Barcelona Clinic Liver Cancer, BCLC). The tumor burden is determined by the number of tumors, size of tumor, portal vein invasion, or presence of extrahepatic metastasis. Here, the functional reserve of the liver is determined according to the Child-Pugh staging system (consists of serum albumin and bilirubin levels, the presence of acid and encephalopathy, prothrombin time/INR findings) and the physical condition is determined according to the performance classification of the Eastern Cooperative Oncology Group (ECOG). This staging system and accordingly, the overall treatment approach are summarized in Table $1(1,2)$.

While only $30 \%-40 \%$ of patients are appropriate for curative treatment (resection, transplantation and ablation for small lesions), the vast majority of about $60 \%$ is in the middle (B) or advanced (C) stage (2). The general prognosis is poor in these patients with no potential curative treatment. Until now, the main treatment options in these patients were transarterial embolization (TAE), transarterial chemoembolization (TACE), or TACE with drug-releasing particles. Evidences of successful survival recovery with TACE have been presented (3). However, TACE is no longer applied to patients with large tumor burden, vascular invasion, and/or failure of liver function with or without a decrease in performance (3). On the other hand, tyrosine multikinase inhibitors administered as a systemic treatment in the advanced stage have been 
shown to have a beneficial effect on survival, but side effects restricting the treatment regimen are often reported (4).

The main treatment options in metastatic liver tumors, particularly in colorectal tumors, are surgery and chemotherapy, and locoregional therapies are also preferred in appropriate patients (5).

In recent years, radioembolization (RE) performed with yttrium-90 (Y-90) microspheres is among the locoregional treatment options for primary and metastatic liver tumors. The aim of this treatment is to ensure the distribution of an efficient radiation dose to tumor tissues in the liver and while doing this, to give the minimum dose of radiation that is not harmful for the intact liver tissue. In this article, the techniques and mechanisms of RE treatment as well as the indications, efficacy, and complications of RE treatment in primary and metastatic liver tumors are reviewed.

\section{Radioembolization Concept}

Radioembolization, which is also called as selective intraarterial RE or Y-90 microsphere therapy, is an intraarterial locoregional treatment method applied to primary and secondary liver tumors for palliative purposes. This process is performed with the infusion of the microspheres loaded with properly prepared Y-90 to the tumor site through hepatic artery catheterization in the interventional radiology unit. It is intended to protect the normal tissues while maximum radiation therapy is provided to the lesion because the accumulation of microspheres is higher in the tumor, particularly in the peripheral zone, than in the normal liver tissue.

Y-90 used in the radionuclide treatment is a pure beta emitter radionuclide with the average energy of $0.937 \mathrm{MeV}$, average tissue penetration of $2.5 \mathrm{~mm}$ (maximum $10 \mathrm{~mm}$ ), and halflife of $64.2 \mathrm{~h}$ (2.6 days); it turns into stable zirconium-90. Ionizing radiation has an effect on direct and indirect DNA damage in the tissue. In total, $75 \%$ of this is indirect damage. High-energy radiation and secondary electrons formed by impinging on a water molecule in the cell may cause direct DNA damage. Furthermore, the water molecule turns into highly reactive free radical molecules as a result of interaction with radiation and causes damage to adjacent DNA in an indirect manner. Oxygen should be present in the environment for the free radicals to cause damage; damage can be repaired in a hypoxic environment.

Radioembolization performed with intra-arterial injection of microspheres loaded with Y-90 is a form of brachytherapy. Like other intra-arterial therapies, this treatment focuses on the arterial bed of hepatic tumors. The external radiotherapy (RT) is thought to be ineffective in the treatment of many of unresectable liver tumors because the dose required for the cure is beyond the radiation tolerance of the entire liver. When the entire liver received $>30$ Gy dose for more than 3 weeks, damage risk was seen depending on fatal radiation around $70 \mathrm{~Gy}$, but this is much higher than the tolerance dose of the normal liver tissue. In addition, HCC is a radiosensitive tumor, and many studies have shown that local RT contributes to tumor response in HCC and overall survival. Various techniques such as 3-dimensional conformal RT, stereotactic RT, proton beam RT, and interstitial brachytherapy have been developed to overcome liver tolerance issues (7-9). Radioembolization, which is the subject of this article, is a form of treatment with radiation where a higher dose is given to liver tumors.

Y-90 microspheres have two different commercial forms connected with microspheres in resin (SIR-Spheres ${ }^{\circ}$, SirtexMedical, LaneCove, Australia) and glass (TheraSphere ${ }^{\circ}$, MDS Nordion, Kanata, ON, Canada) structures. The properties of resin and glass microspheres are summarized in Table 2 .

\section{Radioembolization Application Principles}

Y-90 microsphere RE application is a multidisciplinary team work that involves hepatologists, oncologists, interventional radiologists, and nuclear medicine specialists. Diagnostic angiography is performed a few weeks before the treatment. During the angiography, treatment simulation is performed using 3-5 mCi (111-185 MBq) Tc-99m macroaggregated albumin (MAA) that has similar characteristics to Y-90 microspheres. After this application, planar and tomographic scintigra-

Table 1. Summary of BCLC staging system in hepatocellular carcinoma

\begin{tabular}{|c|c|c|}
\hline Stage & Definition & Treatment \\
\hline $\begin{array}{l}\text { BCLC } 0 \\
\text { (Very early } \\
\text { stage) }\end{array}$ & $\begin{array}{l}\text { One asymptomatic nodule } \\
\text { smaller than } 2 \mathrm{~cm} \text { without } \\
\text { vascular invasion and } \\
\text { well-preserved liver function } \\
\text { (Child-Pugh A) }\end{array}$ & $\begin{array}{l}\text { Curative } \\
\text { treatment options } \\
\text { (Surgical resection, } \\
\text { local ablation/ } \\
\text { transplantation) }\end{array}$ \\
\hline $\begin{array}{l}\text { BCLCA } \\
\text { (Early stage) }\end{array}$ & $\begin{array}{l}\text { A single nodule at any size } \\
\text { or maximum } 3 \text { nodules less } \\
\text { than } 3 \mathrm{~cm} \text { (Child-Pugh } A \text { or } B \text { ) }\end{array}$ & $\begin{array}{l}\text { Curative } \\
\text { treatment options } \\
\text { (Surgical resection, } \\
\text { local ablation/ } \\
\text { transplantation) }\end{array}$ \\
\hline $\begin{array}{l}\text { BCLCB } \\
\text { (Intermediate } \\
\text { stage) }\end{array}$ & $\begin{array}{l}\text { A large number of tumor } \\
\text { focuses without vascular } \\
\text { invasion or extrahepatic } \\
\text { metastasis (Child-Pugh } \\
\text { class A or B) }\end{array}$ & TACE \\
\hline $\begin{array}{l}\text { BCLCC } \\
\text { (Advanced } \\
\text { stage) }\end{array}$ & $\begin{array}{l}\text { The stage when vascular } \\
\text { invasion or extrahepatic } \\
\text { metastasis and cancer } \\
\text { associated symptoms are } \\
\text { seen (Child-Pugh A or B) }\end{array}$ & $\begin{array}{l}\text { Tyrosine } \\
\text { multikinase } \\
\text { inhibitors } \\
\text { (such as sorafenib) }\end{array}$ \\
\hline $\begin{array}{l}\text { BCLCD } \\
\text { (End stage) }\end{array}$ & $\begin{array}{l}\text { The stage when Pugh C and } \\
\text { cancer-related symptoms with } \\
\text { any tumor stage are seen }\end{array}$ & Support care \\
\hline
\end{tabular}


Table 2. Properties of Y-90 resin and glass microspheres

\begin{tabular}{|c|c|c|}
\hline Properties & SIR-Spheres ${ }^{\circledR}$ & TheraSphere ${ }^{\circledR}$ \\
\hline Material & resin & glass \\
\hline Particle size $(\mu \mathrm{m})$ & $20-60$ & $20-30$ \\
\hline $\begin{array}{l}\text { The number of spheres per } \\
\text { vial (million) }\end{array}$ & $40-80$ & $1.2-8$ \\
\hline Specific weight & Low & High \\
\hline Embolic effect & Medium & Mild \\
\hline Activity per sphere (Bq) & $40-70$ & 2,500 \\
\hline Existing activity (GBq) & 3 & $3,5,7,10,15,20$ \\
\hline Manipulation for the application & Required & Not required \\
\hline \multicolumn{3}{|c|}{$\begin{array}{l}\text { Y-90: Yttrium-90; SIR-Spheres }{ }^{\circledR} \text { : SirtexMedical, LaneCove, Australia; TheraS- } \\
\text { phere®: MDS Nordion, Kanata, ON, Canada; } \mu \text { m: micrometer; Bq: becquerel; } \\
\text { GBq: giga-becquerel }\end{array}$} \\
\hline
\end{tabular}

phy images (single photon emission computed tomography, SPECT) are taken, and SPECT-CT fusion images superimposed on computed tomography (CT) are obtained. Thus, it becomes possible to measure the hepatopulmonary shunt, to identify the unnoticed collateral vessels owing to the hepatic artery that will cause microspheres to escape or move to the gastrointestinal tract or other extrahepatic organs, and to predict how the therapeutic agents will distribute in the tumor area and normal liver tissue. Arteriovenous anastomoses or shunts within the tumor are the characteristics of the tumor. The shunt ratio in HCC with extensive tumor burden is more than that in metastatic tumor. An amount of microspheres pass to the lung capillary network bypassing the hepatic capillary bed. The radiation pneumonitis that may occur as a result of this is an inflammatory reaction, and pneumonia symptoms occur (dry cough, progressive dyspnea, restrictive respiratory defects, deterioration of lung functions, and even death). By drawing the interest areas of both lungs and liver over the planar thorax and abdomen anterior and posterior images, the pulmonary shunt ratio is calculated through the geometric mean method; the cumulative radiation dose that the lungs will be exposed to is determined. Preclinical and clinical studies conducted with Y-90 microspheres have demonstrated that the highest tolerable dose for the lung is $30 \mathrm{~Gy}$ in a single injection (10, 11). The cumulative dose of radiation absorbed by the lungs must not exceed $50 \mathrm{~Gy}$ in cases where the treatment is applied several times. The total amount of the activity to be applied to the liver may need to be reduced depending on the pulmonary shunt value; the implementation of the treatment may even be contraindicated. In the case of unexpected accumulation of an excessive amount of Y-90 microspheres in the stomach, duodenum, gall bladder, pancreas, and mesentery, this treatment is not applicable because severe complications (such as gastrointestinal ulceration, bleeding, gastritis, duodenitis, cholecystitis, pancreatitis, radiation dermatitis, and pneumonia) may arise $(12,13)$. Systemic treatments often deteriorate the hepatic artery flow by affecting the morphological structure in neoplastic tissue and even in normal parenchyma. All these changes may affect the 99mTc-MAA scintigraphy and thus, Y-90 microsphere distribution. In this respect, special care should be paid to irinotecan and oxaliplatin that can cause sinusoidal obstruction syndrome and to 5-FU and gemcitabine that can increase the risk of liver toxicity. Capecitabine should be interrupted for at least 2 months before radioembolization because it increases the risk of liver disease caused by radiation (14-16). However, it is unclear whether these drugs are contraindicated for radioembolization. Because antiangiogenic drugs (bevacizumab, sorafenib) may restrict the accumulation of MAA in tumoral tissue, secondary to occurring hypoxia, it is recommended to discontinue these drugs at least 8 weeks before the assessment (17).

In patients deemed appropriate, Y-90 microspheres are provided to the targeted liver zone through the intraarterial route at a certain dose after the order and bedside preparation. Imaging is possible in a gamma camera (SPECT) with the bremsstrahlung radiation of Y-90 and in positron emission tomography (PET) with positron emission, and Y-90 microsphere distribution can be evaluated. Because of the better spatial resolution and higher image quality, PET-CT is advantageous in determining microsphere distribution more accurately, particularly in small lesions, and SPECT-CT has shorter acquisition time benefits; thus, either option may be preferred in imaging. If there is a gastrointestinal tract (GIT) leakage in the imaging performed after the treatment, proton pump inhibitors should be started immediately at the first hour. The images of a patient with HCC diagnosis in whom Y-90 RE treatment was performed after MAA treatment simulation and partial regression was detected in the follow-up on CT scan are shared in Figure 1. The images of a patient who had a vascular variation characterized by MAA escape to the spleen, diaphragm and anterior abdominal wall, and who was inappropriate for RE treatment are shared in Figure 2.

\section{Indications and Clinical Results}

Primary Liver Tumors (HCC, intrahepatic cholangiocellular carcinoma): Because RE has recently entered clinical practice, the results of the phase 3 clinical trial are still few and RE treatment is not available in some application guidelines. The randomized clinical study of RE and sorafenib therapy in HCC patients with portal vein thrombosis is being continued by the BCLC group. In the National Comprehensive Cancer Network (NCCN) guidelines, RE is recommended as a treatment option for HCC patients in the following cases (18): in patients with Child-Pugh A-B7, non-portal hypertension, and sufficient liver reserve; as a bridge treatment option in candidates for transplantation for unresectable tumor due to inadequate hepatic reserve or tumor location; as a locoregional treatment option in patients who are unresectable and not candidates for transplantation because of insufficient hepatic reserve or tumor location; and as a locoregional treatment choice in local or minimal extrahepatic disease that is inoperable due to performance status or comorbidities. 
For intrahepatic cholangiocellular carcinoma, it is recommended as a locoregional treatment option in unresectable and metastatic disease. In addition, after $\mathrm{R} 2$ resection, it can be recommended as an adjuvant treatment or locoregional treatment option in residual local disease (18).

Although the main application area of Y-90 RE has been reported as nonresectable advanced-stage HCC in the initial reports in the literature, the application area has been expanded in recent years. Y-90 RE can induce complete necrosis at the target lesions and can therefore be used as a bridge for liver transplantation (19). The median overall survival after the application of Y-90 microsphere has been reported to be around 26 months in early-stage patients (BCLC A) in recent series (20-22). Thus, it can be used as a bridge for reducing the losses on the patient waiting list of transplantation (23). In a study conducted with Y-90 RE, the median survival was detected as 17.2 months and median progression time as 13.3 months in 83 patients in the intermediate-stage group (BCLC B) (20). Three features seen in advanced HCC (BCLC C) worsen the prognosis, regardless of treatment modalities: impairment in performance, presence of extrahepatic disease, and/or portal vein invasion. The recommended treatment in this group of patients is tyrosine kinase inhibitors. The median survival time is between 6.5 and 9.7 months with sorafenib $(24,25)$. Radioembolization may provide a similar median survival time (6-13 months) (22-26). Khan et al. (27) suggested that $\mathrm{RE}$ is quite good in HCC for control of existing lesions but should be combined with systemic treatment owing to newly developing lesions.

Portal Vein Thrombosis: Because of dual feeding of the liver through the hepatic artery and portal vein, the rehabilitation of potential parenchymal damage that may occur as a result of hepatic artery embolization is possible. Macrovascular occlusion of the portal vein or branches is considered to be a poor prognostic factor. This situation is a general indication of extensive intrahepatic tumor growth, extrahepatic spread, progressive functional impairment, and progressive disease and often considered to be a contraindication for TACE (28). However, because RE has no macroembolic effect, it can be applied to patients with portal vein thrombosis $(29,30)$. Al-
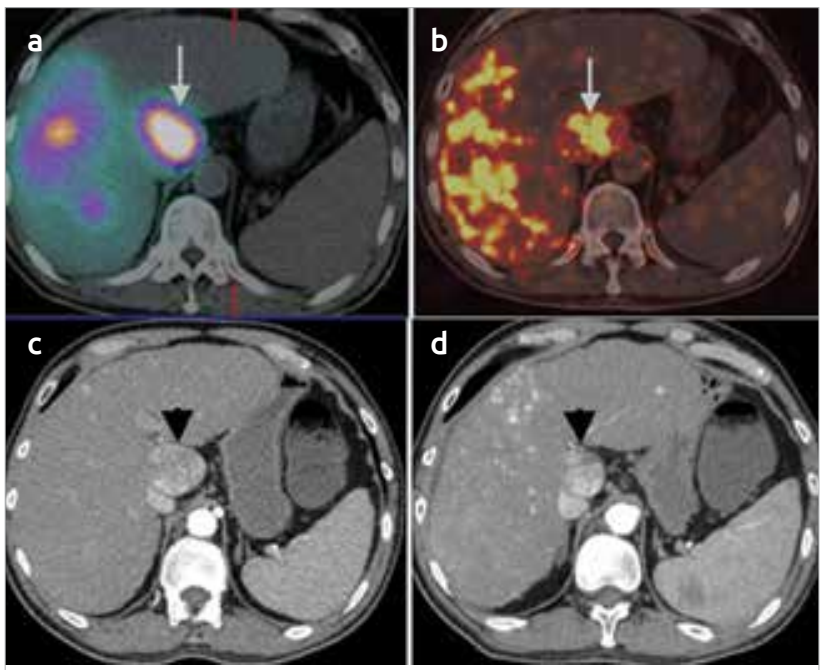

Figure 1. a-d. In the SPECT-CT fusion images taken after Tc-99m macroaggregated albumin (MAA) was provided to the right hepatic artery of a 62-year-old male patient with multiple HCC by placing a microcatheter in the angiography unit (a) and in a PET-CT fusion image taken after the administration of Y-90 glass microspheres 2 weeks later through the same place (b), the distribution of the activity in the right lobe of the liver is observed intensely in tumor regions and at lower levels in normal parenchyma. The caudate lobe lesion indicated by the arrow is the biggest HCC focus, and the accumulation of MAA and Y-90 microspheres is observed. In the contrast-enhanced CT axial sections of the patient before the treatment (c) and after 6 months (d), partial regression in this lesion in the caudate lobe is seen (black arrowhead)

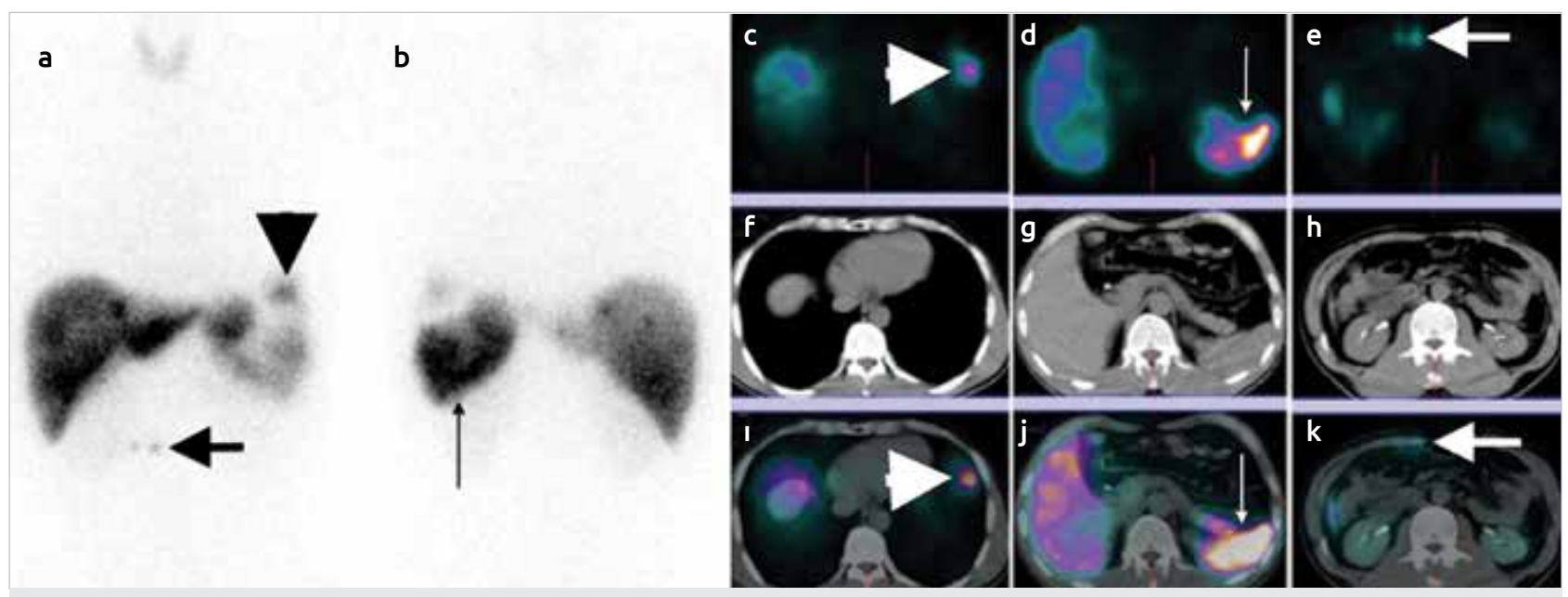

Figure 2. a-k. In the planar anterior (a) and posterior (b) images taken after Tc-99m MAA was provided to the 37-yearold male patient with neuroendocrine tumor and multiple liver metastases and in SPECT (c, $d, e), C T(f, g, h)$, and fusion $(i, j, k)$ images, MAA leakage is seen on the left, focal into the diaphragm (arrowhead), intense diffuse into the spleen (thin arrow), and as several focuses into the front wall of the abdomen on the right (arrow). RE treatment could not be provided to this patient 
though the width of portal thrombosis influences the survival time, no significant difference was found in terms of toxicity in the groups with and without portal vein thrombosis (29, 31). According to a newly conducted study, in HCC patients with portal vein thrombosis, chemoembolization performed with particles secreting a drug with doxorubicin that leads to tumor necrosis at a high concentration was reported to provide better tumor control and improvement in survival than $\mathrm{RE}$, and it was recommended that more studies should be conducted on this issue (32).

Because the main cause of death in most patients with hepatocellular carcinoma is not metastases, local treatments can also be applied in the presence of metastatic burden in the nonvital organs such as bones and lymph nodes. However, extrahepatic disease is an indication of the aggressiveness of the tumor and the median survival is less in metastatic patients after RE (5.4-7.4 months). Radioembolization can be used in progressive disease where resection, percutaneous ablation, or transarterial chemotherapy is contraindicated $(20,22,33)$. Child-Pugh score greater than B7, more intrahepatic and extrahepatic tumor burden, acute or chronic renal failure, acute or severe chronic lung disease, and conditions where hepatic artery catheterization is contraindicated (such as clotting disorder, contrast allergy) are accepted as contraindications for the application of radioembolization (14).

Radioembolization before Resection or Transplantation: When a single lobe is treated, while atrophy develops in the lobe being treated, an increase in the contralateral lobe volume (hypertrophy) can be seen; this is defined as "radiation lobectomy." Compared with other transarterial treatments, one of the most important advantages of this treatment is contralateral hypertrophy, and this may also be effective not only in HCC but also in the other patient groups with liver metastasis. In cases where such a small tissue is left that it enables no resection type in terms of functional capacity, there is evidence showing that lobar or segmental selective RE provides surgical possibilities by causing ipsilateral segmental and contralateral lobar hypertrophy. Therefore, RE can be an important component of a multimodality treatment concept for curative purposes (34-36).

It is difficult to predict the prognosis in patients with hepatocellular carcinoma because of the association of cirrhosis and life-threatening carcinoma, and transplantation is considered as the best treatment option because it eliminates not only the tumor but also the underlying cirrhosis. However, 50\%-70\% of HCC cases are determined at stages when radical treatment (resection or transplantation) cannot be implemented (37). According to Milan criteria, the benefit of transplantation is limited with the cases of one tumor not bigger than 5 $\mathrm{cm}$ or three tumors, none of which is bigger than $3 \mathrm{~cm}$ (38). The aim is to reduce the tumor burden prior to the transplantation, to make unresectable tumors resectable prior to surgical resection, or to facilitate the surgical procedure. Riaz et al. examined the pathological findings after Y-90 RE that they applied to 35 patients for the purpose of transplantation or bridge for resection. Accordingly, they detected complete pathological necrosis in $89 \%$ of the small lesions $(1-3 \mathrm{~cm})$ and in $65 \%$ of the larger lesions $(3-5 \mathrm{~cm})$. Compared with the pathological findings after TACE, better antitumoral effects were obtained after RE (39).

Combination of RE with Systemic Therapies: Because most HCC cases are detected at an intermediate or advanced stage, local ablation, resection, or transplantation cannot be a treatment option. Furthermore, unfortunately, there is no effective systemic chemotherapeutic treatment in these patients. Monoclonal antibodies (such as rituximab, bevacizumab, cetuximab) and tyrosine kinase inhibitors (such as sorafenib, erlonitib, sunitinib) provide a more moderate survival benefit than supportive therapy in advanced-stage $\operatorname{HCC}(4,40)$. With the synergistic effect resulting from the combination of the different mechanisms, survival can be increased using radioembolization and sorafenib together. It was shown that 23-month survival could be obtained using a combination of the two treatments in a patient and the hepatopulmonary shunt ratio was reduced using sorafenib prior to RE $(41,42)$.

Liver Metastasis: Colorectal cancer is the third most common cancer. The most common site of metastases is the liver, and the leading cause of death is liver failure due to metastasis. Although the first treatment choice of hepatic metastases is surgical resection, it may be possible with a small number of patients. In unresectable disease, the standard treatment is chemotherapy (fluoro-pyrimidines, oxaliplatin, irinotecan) or systemic treatment with targeted agents (such as monoclonal antibodies) (43). Y-90 RE provides a minimal morbidity and reasonable overall survival in these patients and even a partial benefit in chemotherapy-resistant cases $(44,45)$. In the prognosis study of the colorectal metastatic patients according to the KRAS mutation status, the overall survival with RE treatment was reported to be better in KRAS wild-type than the mutants (46).

Neuroendocrine tumors are rare and account for approximately $0.5 \%$ of all malignancies. Liver metastasis is seen in the majority of patients and is the cause of poor prognosis. The first choice of treatment is surgery for liver metastasis; however, because the lesions are usually numerous or large, there is no chance for surgery. The liver metastases of neuroendocrine tumors are hypervascular, and their blood is largely supplied through the hepatic artery; they are suitable for RE with these characteristics. Although close or better results are reported with TACE in the literature, comparative studies are needed. Radioembolization may provide the control of the tumor and may prepare the patient for other treatment options such as radiofrequency ablation, resection, or transplantation (47).

Breast cancer is the most common cancer in women, and the life-long risk estimate is approximately $10 \%-15 \%$. The prognosis of the local disease is very good (5-year survival 99\%). 
However, $20 \%$ of patients are metastatic (bone, liver, lung, brain), and liver metastasis exists in approximately $15 \%$ of them. The survival benefit of local therapies applied in addition to systemic treatments has been reported in breast cancer patients with liver metastases, and the most benefit has been found in patients with small lesions, receiving limited systemic therapy (48). RE is safe in this group of patients and stops or slows down the progression of lesions that are resistant to chemotherapy or targeted treatment (49). The factors that positively affect the prognosis are the limited extent of the tumor in the liver parenchyma, application of RE after chemotherapy, and radiological response. However, though the liver lesions respond very well because of the presence of extrahepatic metastases in some patients, it does not change the survival much (49).

Uveal malignant melanoma is the most common primary intraocular tumor in adults and tends to metastasize to the liver; death often occurs because of liver failure. There are limited number of studies on the implementation of RE for liver metastases (47).

Although RE treatment has been applied to a limited number of liver metastases of other primary tumors, tumor response close to HCC and colorectal metastasis has been reported (47). With the increase in the literature and experience, RE treatment may become a standard option in all types of primary and secondary liver tumors for which surgery is not intended as a general approach and which do not benefit from routine treatment $(14,29,47)$.

\section{Complications and Countermeasures}

Radiation Pneumonitis: Lung tissue is very sensitive to radiation. Because of arteriovenous shunts in the metastatic lesions, a portion of the Y-90 microspheres provided into the liver through intra-arterial injection enters the lungs, and if this amount is huge, the risk of radiation damage significantly increases. The resulting symptoms are dry cough, progressive dyspnea, restrictive respiratory distress, and even death after a month of application (50). The pulmonary shunt rate is important in Tc-99m-MAA scintigraphy performed prior to the treatment in order to minimize pulmonary side effects.

Liver Toxicity: Cell damage may develop in healthy parts of the liver after RE, and the resulting impairment of the liver function can be identified through laboratory tests and clinical findings. The functional capacity and regeneration ability of the liver are decreased in cirrhotic patients. Furthermore, because of the changes in microvascular patterns and the presence of arteriovenous/arterioportal shunts in cirrhotic patients, expected microsphere distribution may change and liver toxicity may develop. The general opinion is that the dose that a healthy liver parenchyma should receive is below 50 Gy and this limit should even be 40 Gy in a cirrhotic tissue (15). If the cirrhosis does not exist or if there is no intense ter RE, this complication is extremely rare. This complication can be temporary or permanent, and its incidence is less than $10 \%$. Prophylaxis and conservative treatments are recommended with low-dose steroids.

Radiation-Induced Cholecystitis: It occurs when Y-90-loaded reach the gallbladder through the cystic artery. It may be useful to provide the microspheres to the distal part of cystic artery in order to prevent cholecystitis due to radiation. The treatment is conservative in most cholecystitis cases. However, cholecystectomy may be required in patients with emphysematous cholecystitis or gallbladder perforation $(51,52)$.

Gastrointestinal Complications: The main reason for the diffusion of the radioactive microspheres to the extrahepatic organs is the collaterals arising from the extrahepatic connections and hepatic artery. These collaterals must be identified at angiography, and if any, they should be embolized prior to the treatment. In addition to the radiation, because of the embolization and hypoxia caused by the spheres, ulceration and even perforation in the stomach and duodenum may develop (53). Therefore, all extrahepatic connections should be identified and embolized prior to radioembolization. In a study investigating whether gastrointestinal symptoms, besides microsphere leak, developed because of its proximity to the liver, it was reported that despite the close neighborhood, the stomach was not affected by radiation in patients undergoing RE applications in the left lobe of the liver (54).

\section{Treatment Failure Causes}

In total, $80 \%$ of the normal liver is supplied with blood by the portal vein and $20 \%$ by the hepatic artery. However, the blood supply to the tumor tissue occurs to a greater extent through the hepatic artery. The mesenteric system and hepatic arterial bed anatomy involve many variations (45\%-35\%). Commonly, aberrant and accessory branches are considered. Digital subtraction angiography (DSA) successfully shows the vascular anatomy. The veins unseen previously may become more apparent after embolization of the gastroduodenal artery and right gastric artery. In addition, the extrahepatic arteries (such as inferior phrenic, intercostal, and internal mammary) support the adjacent liver tissue. Because of this, tumors in these areas would exhibit a partial response to local treatment or recurrence. Other than that, treatments such as chemoembolization and surgical ligation of the hepatic arteries that were previously applied and could disrupt the normal hepatic structure may cause RE failure (55-57). Treatment with a more optimal dose can be provided to the tumor with the developments in calculation methods of the Y-90 dose. When RE is applied in combination with the radiosensitizing agents, the effectiveness of treatment can increase.

\section{Conclusion}

Y-90 microsphere RE therapy is an effective, well-tolerated, locoregional, and intriguing treatment option that can be applied to primary and metastatic liver tumors with no potential 
curative therapy. The toxicity of the process is low, but because of the potential for serious complications, a multidisciplinary evaluation and rigorous technical application are required.

Peer-review: This manuscript was prepared by the invitation of the Editorial Board and its scientific evaluation was carried out by the Editorial Board.

Author Contributions: Concept - E.B.E., M.A., H.Ö.; Design - E.B.E., M.A., H.Ö.; Supervision - M.A., E.B.E., H.Ö.; Resources - E.B.E.; Materials - E.B.E., H.Ö., M.A.; Data Collection and/or Processing - E.B.E., H.Ö.; Analysis and/or Interpretation - E.B.E., M.A., H.Ö.; Literature Search E.B.E.; Writing Manuscript - E.B.E.; Critical Review - M.A., H.Ö.

Conflict of Interest: No conflict of interest was declared by the authors.

Financial Disclosure: The authors declared that this study has received no financial support.

\section{References}

1. Llovet JM, Brú C, Bruix J. Prognosis of hepatocellular carcinoma: the BCLC staging classification. Semin Liver Dis 1999; 19: 329-10. [CrossRef]

2. Kinoshita A, Onoda H, Fushiya N, Koike K, Nishino H, Tajiri H. Staging systems for hepatocellular carcinoma: Current status and future perspectives. World J Hepatol 2015; 7: 406-24. [CrossRef]

3. Burrel M, Reig M, Forner A, Barrufet M, de Lope CR, Tremosini $S$, et al. Survival of patients with hepatocellular carcinoma treated by transarterial chemoembolisation (TACE) using Drug Eluting Beads. Implications for clinical practice and trial design. J Hepatol 2012; 56: 1330-5. [CrossRef]

4. Llovet JM, Ricci S, Mazzaferro V, Hilgard P, Gane E, Blanc JF, et al. Sorafenib in advanced hepatocellular carcinoma. N Engl J Med 2008; 359: 378-90. [CrossRef]

5. Mahnken AH, Pereira PL, de Baère T. Interventional oncologic approaches to liver metastases. Radiology 2013; 266: 407-30. [CrossRef]

6. Lawrence TS, Robertson JM, Anscher MS, Jirtle RL, Ensminger WD, Fajardo LF. Hepatic toxicity resulting from cancer treatment. Int J Radiat Oncol Biol Phys 1995; 31: 1237-48. [CrossRef]

7. McGinn CJ, Ten Haken RK, Ensminger WD, Walker S, Wang S, Lawrence TS. Treatment of intrahepatic cancers with radiation doses based on a normal tissue complication probability model. J Clin Oncol 1998; 16: 2246-52.

8. Ben-Josef E, Normolle D, Ensminger WD, Walker S, Tatro D, Ten Haken RK, et al. PhaseII trial of high-dose conformal radiation therapy with concurrent hepatic artery floxuridine for unresectable intrahepatic malignancies. J Clin Oncol 2005; 23: 8739-47. [CrossRef]

9. Mornex F, Girard N, Beziat C, Kubas A, Khodri M, Trepo C, et al. Feasibility and efficacy of high-dose three-dimensional-conformal radiotherapy in cirrhotic patients with small-size hepatocellular carcinoma non-eligible for curative therapies mature results of the French Phase II RTF-1 trial. Int J Radiat Oncol Biol Phys 2006; 66: 1152-8. [CrossRef]

10. Leung TW, Lau WY, Ho SK, Ward SC, Chow JH, Chan MS, et al. Radiation pneumonitis after selective internal radiation treatment with intraarterial 90yttrium-microspheres for inoperable hepatic tumors. Int J Radiat Oncol Biol Phys 1995; 33: 919-24. [CrossRef]

11. Yorke ED, Jackson A, Rosenzweig KE, Braban L, Leibel SA, Ling CC. Correlation of dosimetric factors and radiation pneumonitis for non-small-cell lung cancer patients in a recently completed dose escalation study. Int J Radiat Oncol Biol Phys 2005; 63: 672-82. [CrossRef]
12. Leong QM, Lai HK, Lo RG, Teo TK, Goh A, Chow PK. Radiation dermatitis following radioembolization for hepatocellular carcinoma: a case for prophylactic embolization of a patent falciform artery. J Vasc Interv Radiol 2009; 20: 833-6. [CrossRef]

13. Riaz A, Lewandowski RJ, Kulik LM, Mulcahy MF, Sato KT, Ryu RK, et al. Complications following radioembolization with yttrium-90 microspheres: a comprehensive literature review. J Vasc Interv Radiol 2009; 20: 1121-30. [CrossRef]

14. Giammarile F, Bodei L, Chiesa C, Flux G, Forrer F, Kraeber-Bodere F, et al. Therapy, Oncology and Dosimetry Committees. EANM procedure guideline for the treatment of liver cancer and liver metastases with intra-arterial radioactive compounds. Eur J Nucl Med Mol Imaging 2011; 38: 1393-406. [CrossRef]

15. Lau WY, Kennedy AS, Kim YH, Lai HK, Lee RC, Leung TW, et al. Patient selection and activity planning guide for selective internal radiotherapy with yttrium-90 resin microspheres. Int J Radiat Oncol Biol Phys 2012; 82: 401-7. [CrossRef]

16. Murthy R, Nunez R, Szklaruk J, Erwin W, Madoff DC, Gupta S, et al. Yttrium-90 microsphere therapy for hepatic malignancy: devices, indications, technical considerations, and potential complications. Radiographics 2005; 25(Suppl 1): S41-55. [CrossRef]

17. Ahmadzadehfar H, Sabet A, Meyer C, Habibi E, Biersack HJ, Ezzid$\operatorname{din} \mathrm{S}$. The importance of Tc-MAA SPECT/CT for therapy planning of radioembolization in a patient treated with bevacizumab. Clin Nucl Med 2012; 37: 1129-30. [CrossRef]

18. NCCN Clinical Practice Guidelines in Oncology, Hepatobiliary cancers Version 2.2015, www.nccn.org.

19. Riaz A, Kulik L, Lewandowski RJ, Ryu RK, Giakoumis Spear G, Mulcahy MF, et al. Radiologic-pathologic correlation of hepatocellular carcinoma treated with internal radiation using yttrium-90 microspheres. Hepatology 2009; 49: 1185-93. [CrossRef]

20. Salem R, Lewandowski RJ, Mulcahy MF, Riaz A, Ryu RK, Ibrahim $S$, et al. Radioembolization for hepatocellular carcinoma using Yttrium-90 microspheres: a comprehensive report of long-term outcomes. Gastroenterology 2010; 138: 52-64. [CrossRef]

21. Salem R, Lewandowski RJ, Kulik L, Wang E, Riaz A, Ryu RK, et al. Radioembolization results in longer time-to-progression and reduced toxicity compared with chemoembolization in patients with hepatocellular carcinoma. Gastroenterology 2011; 140: 497-11. [CrossRef]

22. Sangro B, Carpanese L, Cianni R, Golfieri R, Gasparini D, Ezziddin $S$, et al. European Network on Radioembolization with Yttrium-90 Resin Microspheres (ENRY).Survival after yttrium-90 resin microsphere radioembolization of hepatocellular carcinoma across Barcelona clinic liver cancer stages: a European evaluation. Hepatology 2011; 54: 868-78. [CrossRef]

23. Heckman JT, Devera MB, Marsh JW, Fontes P, Amesur NB, Holloway SE, et al. Bridging locoregional therapy for hepatocellular carcinoma prior to liver transplantation. Ann Surg Oncol 2008; 15: 3169-77. [CrossRef]

24. Cheng AL, Kang YK, Chen Z, Tsao CJ, Qin S, Kim JS, et al. Efficacy and safety of sorafenib in patients in the Asia-Pacific region with advanced hepatocellular carcinoma: a phase III randomised, double-blind, placebo-controlled trial. Lancet Oncol 2009; 10: 2534. [CrossRef]

25. Bruix J, Raoul JL, Sherman M, Mazzaferro V, Bolondi L, Craxi A, et al. Efficacy and safety of sorafenib in patients with advanced hepatocellular carcinoma: subanalyses of a phase III trial. J Hepatol 2012; 57: 821-9. [CrossRef]

26. Mazzaferro V, Sposito C, Bhoori S, Romito R, Chiesa C, Morosi C, et al. Yttrium-90 radioembolization for intermediate-advanced hepatocellular carcinoma: a phase 2 study. Hepatology 2013; 57: 1826-37. [CrossRef] 
27. Khor AY, Toh Y, Allen JC, Ng DC, Kao YH, Zhu G, et al. Survival and pattern of tumor progression with yttrium-90 microsphere radioembolization in predominantly hepatitis B Asian patients with hepatocellular carcinoma. Hepatol Int 2014; 8: 395-404. [CrossRef]

28. Bruix J, Sherman M. American Association for the Study of Liver Diseases. Management of hepatocellular carcinoma: an update. Hepatology 2011; 53: 1020-2. [CrossRef]

29. Sato K, Lewandowski RJ, Bui JT, Omary R, Hunter RD, Kulik L, et al. Treatment of unresectable primary and metastatic liver cancer with yttrium-90 microspheres (TheraSphere): assessment of hepatic arterial embolization. Cardiovasc Intervent Radiol 2006; 29: 522-9. [CrossRef]

30. Bilbao JI, de Martino A, de Luis E, Díaz-Dorronsoro L, Alonso-Burgos A, Martínez de la Cuesta A, et al. Biocompatibility, inflammatory response, and recannalization characteristics of nonradioactive resin microspheres: histological findings. Cardiovasc Intervent Radiol 2009; 32: 727-36. [CrossRef]

31. Woodall CE, Scoggins CR, Ellis SF, Tatum CM, Hahl MJ, Ravindra $\mathrm{KV}$, et al. Is selective internal radioembolization safe and effective for patients with inoperable hepatocellular carcinoma and venous thrombosis? J Am Coll Surg 2009; 208: 375-82. [CrossRef]

32. Akinwande O, Kim D, Edwards J, Brown R, Philips P, Scoggins C, et al. Is radioembolization (90Y) better than doxorubicin drug eluting beads (DEBDOX) for hepatocellular carcinoma with portal vein thrombosis? A retrospective analysis. Surg Oncol 2015; 24: 270-5. [CrossRef]

33. Uchino K, Tateishi R, Shiina S, Kanda M, Masuzaki R, Kondo Y, et al. Hepatocellular carcinoma with extrahepatic metastasis: clinical features and prognostic factors. Cancer 2011; 117: 4475-83. [CrossRef]

34. Jakobs TF, Saleem S, Atassi B, Reda E, Lewandowski RJ, Yaghmai $\mathrm{V}$, et al. Fibrosis, portal hypertension, and hepatic volume changes induced by intra-arterial radiotherapy with 90yttrium microspheres. Dig Dis Sci 2008; 53: 2556-63. [CrossRef]

35. Garden OJ. Pushing the limits of surgical management in patients with hepatocellular carcinoma. Br J Surg 2011; 98: 1183-4. [CrossRef]

36. Anaya DA, Blazer DG, Abdalla EK. Strategies for resection using portal vein embolization: hepatocellular carcinoma and hilar cholangiocarcinoma. Semin Intervent Radiol 2008; 25: 110-22. [CrossRef]

37. Llovet JM, Di Bisceglie AM, Bruix J, Kramer BS, Lencioni R, Zhu $\mathrm{AX}$, et al. Design and endpoints of clinical trials in hepatocellular carcinoma. J Natl Cancer Inst 2008; 100: 698-711. [CrossRef]

38. Azzam AZ. Liver transplantation as a management of hepatocellular carcinoma. World J Hepatol 2015; 7: 1347-54. [CrossRef]

39. Riaz A, Kulik L, Lewandowski RJ, Ryu RK, Giakoumis Spear G, Mulcahy MF, et al. Radiologic-pathologic correlation of hepatocellular carcinoma treated with internal radiation using yttrium-90 microspheres. Hepatology 2009; 49: 1185-93. [CrossRef]

40. Rimassa L, Santoro A. Sorafenib therapy in advanced hepatocellular carcinoma: the SHARP trial. Expert Rev Anticancer Ther 2009; 9: 739-45. [CrossRef]

41. Chaudhury PK, Hassanain M, Bouteaud JM, Alcindor T, Nudo CG, Valenti D, et al. Complete response of hepatocellular carcinoma with sorafenib and Y radioembolization. Curr Oncol 2010; 17: 67-9.

42. Theysohn JM, Schlaak JF, Müller S, Ertle J, Schlosser TW, Bockisch A, et al. Selective internal radiation therapy of hepatocellular carcinoma: potential hepatopulmonary shunt reduction after sorafenib administration. J Vasc Interv Radiol 2012; 23: 949-52. [CrossRef]
43. Cunningham D, Atkin W, Lenz HJ, Lynch HT, Minsky B, Nordlinger B, et al. Colorectal cancer. Lancet 2010; 375: 1030-47. [CrossRef]

44. Rosenbaum CE, Verkooijen HM, Lam MG, Smits ML, Koopman $\mathrm{M}$, van Seeters T, et al. Radioembolization for treatment of salvage patients with colorectal cancer liver metastases: a systematic review. J Nucl Med 2013; 54: 1890-5. [CrossRef]

45. Abbott AM, Kim R, Hoffe SE, Arslan B, Biebel B, Choi J, et al. Outcomes of therasphere radioembolization for colorectal metastases. Clin Colorectal Cancer 2015; 14: 146-53. [CrossRef]

46. Lahti SJ, Xing M, Zhang D, Lee JJ, Magnetta MJ, Kim HS. KRAS status as an independent prognostic factor for survival after Yttrium90radioembolization therapy for unresectable colorectal cancer liver metastases. J Vasc Interv Radiol 2015; 26: 1102-11. [CrossRef]

47. Zurkiya O, Ganguli S. Beyond hepatocellular carcinoma and colorectal metastasis: the expanding applications of radioembolization. Front Oncol 2014; 4: 150. [CrossRef]

48. Seidensticker M, Garlipp B, Scholz S, Mohnike K, Popp F, Steffen I, et al. Locally ablative treatment of breast cancer liver metastases: identification of factors influencing survival (the Mammary Cancer Microtherapy and Interventional Approaches (MAMMA MIA) study). BMC Cancer 2015; 15: 517. [CrossRef]

49. Gordon AC, Gradishar WJ, Kaklamani VG, Thuluvath AJ, Ryu RK, Sato KT, et al. Yttrium-90 radioembolization stops progression of targeted breast cancer liver metastases after failed chemotherapy. J Vasc Interv Radiol 2014; 25: 1523-32. [CrossRef]

50. Leung TW, Lau WY, Ho SK, Ward SC, Chow JH. Radiation pneumonitis after selective internal radiation treatment with intraarterial 90yttrium-microspheres for inoperable hepatic tumors. Int J Radiat Oncol Biol Phys 1995; 33: 919-24. [CrossRef]

51. Salem R, Lewandowski RJ, Atassi B, Gordon SC, Gates VL, Barakat $\mathrm{O}$, et al. Treatment of unresectable hepatocellular carcinoma with use of $90 \mathrm{Y}$ microspheres (TheraSphere): safety, tumor response, and survival. J Vasc Interv Radiol 2005; 16: 1627-39. [CrossRef]

52. Nakamura H, Kondoh H. Emphysematous cholecystitis: complication of hepatic artery embolization. Cardiovasc Intervent Radiol 1986; 9: 152-3. [CrossRef]

53. Yip D, Allen R, Ashton C, Jain S. Radiation-induced ulceration of the stomach secondary to hepatic embolization with radioactive yttrium microspheres in the treatment of metastatic colon cancer. J Gastroenterol Hepatol 2004; 19: 347-9. [CrossRef]

54. Gates VL, Hickey R, Marshall K, Williams M, Salzig K, Lewandowski RJ, et al. Gastric injury from $90 \mathrm{Y}$ to left hepatic lobe tumors adjacent to the stomach: fact or fiction? Eur J Nucl Med Mol Imaging 2015; 42: 2038-44. [CrossRef]

55. Chung JW, Kim HC, Yoon JH, Lee HS, Jae HJ, Lee W, et al. Transcatheter arterial chemoembolization of hepatocellular carcinoma: prevalence and causative factors of extrahepatic collateral arteries in 479 patients. Korean J Radiol 2006; 7: 257-66. [CrossRef]

56. Miyayama S, Yamashiro M, Okuda M, Yoshie Y, Nakashima Y, Ikeno H, et al. The march of extrahepatic collaterals: analysis of blood supply to hepatocellular carcinoma located in the bare area of the liver after chemoembolization. Cardiovasc Intervent Radiol 2010; 33: 513-22. [CrossRef]

57. Seki H, Kimura M, Yoshimura N, Yamamoto S, Ozaki T, Sakai K. Development of extrahepatic arterial blood supply to the liver during hepatic arterial infusion chemotherapy. Eur Radiol 1998; 8: 1613-8. [CrossRef] 